\title{
ANALISIS PENGARUH CAR, FDR, BOPO DAN NPF TERHADAP PROFITABILITAS PADA PT BANK MUAMALAT INDONESIA TBK
}

\author{
Desi Ariyani \\ Universitas Marcubuana Jakarta \\ Email: Ariyani_ds@yahoo.co.uk
}

\begin{abstract}
Abstrak: Perbankan Syariah di Indonesia telah memberikan kontribusi positif bagi perekonomian nasional. Hal ini dapat dilihat dari parameter rasio pembiayaan terhadap dana pihak ketiga dan ekuitas (FDR/financing to deposit ratio) yang rata-rata mencapai 105\%. Bandingkan dengan parameter sejenis di perbankan konvensional, LDR (loan to deposit ratio) yang ratarata tidak lebih dari 55\%. Konsep perbankan Syariah yang selalu menjaga keseimbangan antara sektor moneter dan riil memengaruhi tercapainya prestasi itu.
\end{abstract}

Kata Kunci: Profitabilitas, Bank Muamalat, Pengaruh CAR

\section{Pendahuluan}

Pertumbuhan ekonomi suatu bangsa memerlukan pola pengaturan pengolahan sumber-sumber ekonomi yang tersedia secara terarah dan terpadu serta dimanfaatkan bagi peningkatan kesejahteraan masyarakat. Lembagalembaga perekonomian bahu-membahu mengelola dan menggerakkan semua potensi ekonomi agar berguna secara optimal. Lembaga keuangan, khususnya lembaga perbankan mempunyai peranan yang amat strategis dalam menggerakkan roda perekonomian suatu Negara.

Perbankan Syariah di Indonesia telah memberikan kontribusi positif bagi perekonomian nasional. Hal ini dapat dilihat dari parameter rasio pembiayaan terhadap dana pihak ketiga dan ekuitas (FDR/financing to deposit ratio) yang rata-rata mencapai 105\%. Bandingkan dengan parameter sejenis di perbankan 
konvensional, LDR (loan to deposit ratio) yang rata-rata tidak lebih dari 55\%. Konsep perbankan Syariah yang selalu menjaga keseimbangan antara sektor moneter dan riil memengaruhi tercapainya prestasi itu. ${ }^{1}$

Namun krisis moneter dan ekonomi sejak Juli 1997, yang disusul dengan krisis politik nasional telah membawa dampak besar dalam perekonomian nasional. Krisis tersebut telah mengakibatkan perbankan Indonesia yang didominasi oleh bank-bank konvensional mengalami kesulitan yang sangat parah. Keadaan tersebut menyebabkan pemerintah Indonesia terpaksa mengambil tindakan untuk merestrukturisasi dan merekapitalisasi sebagian bank-bank di Indonesia. Lahirnya Undang-Undang No. 10 tahun 1998, tentang Perubahan atas Undang-Undang No. 7 tahun 1992 tentang Perbankan, pada bulan November 1998 telah memberi peluang yang sangat baik bagi tumbuhnya bank-bank syariah di Indonesia. Undang-Undang tersebut memungkinkan bank beroperasi sepenuhnya secara syariah atau dengan membuka cabang khusus syariah.

Ada tiga bank syariah yang bersifat full pledged alias berdiri sendiri sampai saat ini, yaitu Bank Muamalat, Bank Mega Syariah dan Bank Syariah Mandiri. ${ }^{2}$ PT Bank Muamalat Indonesia Tbk didirikan pada tahun 1991, diprakarsai oleh Majelis Ulama Indonesia (MUI) dan Pemerintah Indonesia, dan memulai kegiatan operasinya pada bulan Mei 1992. Dengan dukungan nyata dari eksponen Ikatan Cendekiawan Muslim se-Indonesia (ICMI) dan beberapa pengusaha Muslim, pendirian Bank Muamalat juga menerima dukungan masyarakat, terbukti dari komitmen pembelian saham Perseroan senilai Rp 84 miliar pada saat penandatanganan akta pendirian Perseroan. Selanjutnya, pada acara silaturahmi peringatan pendirian tersebut di Istana Bogor, diperoleh tambahan komitmen dari masyarakat Jawa Barat yang turut menanam modal senilai Rp 106 miliar. $^{3}$

Dari tahun 1998 sampai dengan 2007, total aset Bank Muamalat

1 Media Indonesia 11 Juli 2006 PPN bebani bank Syariah Diakses pada tanggal 10-30-2007 dari htpp://www.halalguide.info/index2.php?option=com_content\&do_ $\mathrm{pdf}=1 \& \mathrm{id}=348$

${ }^{2}$ Reader's Digest Indonesia February 2008 Diakses pada tanggal 10-30-2007 dari http://www.ditplb.or.id/2006/index.php?menu=news\&id_news=4433\&idsek

${ }^{3}$ Di akses pada tanggal 31-10-2008 http://www.muamalatbank.com/profil/label.asp 
Indonesia meningkat mendekati $2.100 \%$, dan ekuitas tumbuh sebesar 2.000\%. Perkembangan tersebut menambah jumlah aset Bank Muamalat menjadi Rp 10,57 triliun di akhir tahun 2007, dengan modal pemegang saham mencapai Rp 846,16 miliar dan pencapaian laba bersih sebesar Rp 145,33 miliar, menjadikannya bank syariah yang paling menguntungkan di Indonesia. Hingga pada juni tahun 2008, Bank Muamalat tetap merupakan bank syariah terkemuka di Indonesia dengan jumlah aktiva sebesar Rp 11,2 triliun, modal pemegang saham sebesar Rp 492,7 miliar serta perolehan laba bersih sebesar Rp 153,5 miliar pada juni 2008. ${ }^{4}$

Perkembangan yang begitu pesat ini barangkali tidak terbayangkan pada 17 ahun silam, saat industri keuangan Syariah baru saja menapaki jalan pertama dengan berdirinya sebuah bank umum Syariah yaitu PT Bank Muamalat Indonesia Tbk. Seiring waktu berlalu, ternyata penerimaan masyarakat yang begitu besar menjadikan industri ini menjadi bintang.

Kunci dari keberhasilan manajemen bank adalah bagaimana bank tersebut bisa merebut hati masyarakat sehingga peranannya sebagai financial intermediary berjalan dengan baik. Bank adalah perantara keuangan masyarakat yaitu perantara dari mereka yang kelebihan uang dengan mereka yang kekurangan uang. ${ }^{5}$

Bank adalah lembaga intermediasi antara para penabung dan investor. Tabungan dapat berguna apabila diinvestasikan, sementara para penabung tidak dapat diharapkan untuk sanggup melakukannya sendiri dengan terampil dan sukses. Nasabah mau menyimpan dananya dibank karena ia percaya bahwa bank dapat memilih alternatif investasi yang baik. ${ }^{6}$

Proses pemilihan investasi itu harus dilakukan dengan seksama, karena kesalahan dalam pemilihan investasi akan mengakibatkan bank tidak dapat memenuhi kewajibannya kepada para nasabahnya. Manajemen tidak bisa semaunya menarik nasabah untuk menyimpan uangnya di bank, tanpa adanya keyakinan bahwa dana itu dapat diinvestasikan secara

${ }^{4}$ Laporan keuangan publikasi Di akses pada tanggal 31-10-2008 http://www. muamalatbank.com

${ }^{5}$ Muchdarsyah Sinungan, manajemen dana bank (Jakarta: Bumi aksara, 2000), h.

${ }^{6}$ Zainul Arifin, Dasar-dasar manajemen bank syariah (Jakarta: pustaka alvabet. 2005), h.121. 
menguntungkan dan dapat dikembalikan ketika dana itu sewaktu-waktu ditarik oleh nasabah atau dana tersebut telah jatuh tempo. Oleh karena itu manajemen harus secara simultan mempertimbangkan berbagai risiko yang akan berpengaruh pada perubahan tingkat laba yang diperoleh. ${ }^{7}$

Bank yang selalu dapat menjaga kinerjanya dengan baik terutama tingkat profitabilitas yang tinggi dan mampu membagikan dividen dengan baik serta prospek usahanya dapat selalu berkembang dan dapat memenuhi ketentuan prudential banking regulation dengan baik, maka kemungkinan nilai saham dari bank yang bersangkutan di pasar sekunder dan jumlah dana dari pihak ketiga yang berhasil dikumpulkan akan naik. Kenaikan nilai saham dan jumlah dana pihak ketiga ini merupakan salah satu indikator naiknya kepercayaan masyarakat kepada bank yang bersangkutan. Kepercayaan dan loyalitas pemilik dana terhadap bank merupakan faktor yang sangat membantu dan mempermudah pihak manajemen bank untuk menyusun strategi bisnis yang baik. Sebaliknya para pemilik dana yang kurang menaruh kepercayaan kepada bank yang bersangkutan maka loyalitasnya pun juga sangat tipis, hal ini sangat tidak menguntungkan bagi bank yang bersangkutan karena para pemilik dana ini sewaktu-waktu dapat menarik dananya dan memindahkannya ke bank lain.

Penilaian terhadap kinerja suatu bank dapat dilakukan dengan melakukan analisis terhadap laporan keuangnya. Laporan keuangan bank berupa neraca memberikan informasi kepada pihak di luar bank, misalnya bank sentral, masyarakat umum, dan investor, mengenai gambaran posisi keuangannya, yang lebih jauh dapat digunakan pihak eksternal untuk menilai besarnya resiko yang ada pada suatu bank. Laporan laba rugi memberikan gambaran mengenai perkembangan bank yang bersangkutan. Pengukuran tingkat kesehatan bank harus dilakukan oleh semua bank baik bank konvensional maupun bank syariah karena terkait dengan kepentingan semua pihak terkait, baik pemilik, pengelola (manajemen) bank, masyarakat pengguna jasa bank, Bank Indonesia selaku otoritas pengawasan bank, dan pihak lainnya. Informasi mengenai kondisi suatu bank dapat digunakan oleh pihak-pihak tersebut untuk mengevaluasi kinerja bank dalam menerapkan

${ }^{7}$ Ibid., h. 121 . 
prinsip kehati-hatian, kepatuhan terhadap ketentuan ketentuan yang berlaku dan manajemen resiko.

Perkembangan metedologi penilaian kondisi bank senantiasa bersifat dinamis sehingga sistem penilaian tingkat kesehatan bank perlu di-review secara periodik untuk menyesuaikan kondisi terkini. Tujuannya adalah agar lebih mencerminkan kondisi bank saat ini dan di waktu yang akan datang. Dalam konteks inilah Bank Indonesia senantiasa melakukan perbaikan kembali terhadap sistem penilaian tingkat kesehatan yang meliputi penyempurnaan pendekatan penilaian kualitatif dan kuantitatif dan penambahan faktor penilaian. Bagi perbankan, hasil akhir penilaian kondisi bank tersebut dapat digunakan sebagai salah satu sarana dalam menetapkan strategi usaha di waktu yang akan datang. Sedangkan bagi Bank Indonesia, antara lain digunakan sebagai sarana penetapan dan implementasi strategi pengawasan bank.

Analisis laporan finansial (financial statement analysis), khususnya mencurahkan perhatian kepada perhitungan rasio agar dapat mengevaluasi keadaan finansial pada masa lalu, sekarang dan memproyeksikan masa yang akan datang. Analisis rasional merupakan bentuk atau cara yang umum digunakan dalam analisis laporan finansial. Dengan kata lain, diantara alat-alat analisis yang digunakan untuk mengukur kekuatan atau kelemahan yang dihadapi pasar dibidang keuangan, adalah analisis ratio (financial ratio analysis). Rasio merupakan alat yang dinyatakan dalam artian relatif maupun absolut untuk menjelaskan hubungan tertentu antara faktor satu dengan yang lainnya dari suatu laporan finansial. Rasio-rasio finansial umumnya diklasifikasikan menjadi 4 macam yaitu rasio likuiditas atau liquidity ratio, rasio laverage/solvabilitas, rasio aktivitas atau activity ratio, dan rasio keuntungan atau profitability ratio. ${ }^{8}$

Rasio profitabilitas digunakan untuk mengukur efektifitas manajemen berdasarkan hasil pengembalian yang dihasilkan dari pinjaman dan investasi. Indikator yang biasa digunakan untuk mengukur kinerja profitabilitas bank adalah ROE (Return on Equity) yaitu rasio yang menggambarkan besarnya kembalian atas total modal untuk menghasilkan keuntungan, ROA (Return on

${ }^{8}$ Sofyan Syafri Harahap, Analisis Kritis Atas Laporan Keuangan (Jakarta: PT RajaGrafindo Persada, 2002), h. 303. 
Assets) yaitu rasio yang menunjukkan kemampuan dari keseluruhan aktiva yang ada dan yang digunakan untuk menghasilkan keuntungan.

\section{Laporan Keuangan Bank Syariah}

Laporan keuangan pada sektor perbankan syariah, sama seperti sektor lainnya, adalah untuk menyediakan informasi yang menyangkut posisi keuangan, kinerja, serta perubahan posisi keuangan aktifitas operasi bank yang bermanfaat dalam mengambil keputusan. ${ }^{9}$

Laporan keuangan (financial statement) menyimpulkan setiap kegiatan dalam setiap bidang fungsional. Neraca mewakili kesimpulan tentang keputusan manajemen yang telah diambil untuk bidang-bidang fungsional dan pernyataan Laba-Rugi mengukur tingkat kemampuan menghasilkan laba (profitability) dari keputusan manajemen selama periode tertentu. ${ }^{10}$ financial statements terdiri atas:

a. Laporan Laba/Rugi (income statements) adalah laporan yang menggambarkan kinerja dan kegiatan usaha bank syariah pada suatu periode tertentu yang meliputi pendapatan dan beban yang timbul pada operasi utama bank dan operasi lainnya. ${ }^{11}$

Penyusunan laporan laba rugi didasarkan pada pendapatan dan biaya diakui secara akrual sedangkan perhitungan distribusi pendapatan/ hasil usaha menggunakan dasar kas. Oleh karena itu, bank syariah harus mampu membedakan pendapatan akrual dan pendapatan yang kasnya sudah diterima.

b. Neraca (balancesheet) berisi laporan sistematis keadaan aktiva/assets, utang/liabilities, dan modal sendiri/owners' equity perusahaan pada saat tertentu. ${ }^{12}$

c. Laporan arus kas (statements of cash flows) merupakan laporan yang menunjukkan penerimaan dan pengeluaran kas dan setara kas pada

${ }^{9}$ Tim Penyusun Pedoman Akuntansi Perbankan Syariah Indonesia (IAI), Pedoman Akuntansi Perbankan Syariah Indonesia (Jakarta: Ikatan Akuntan Indonesia, 2003). h. 1.

${ }^{10}$ Zainul Arifin, Dasar-Dasar Manajemen Bank Syariah, 2005. h.65

${ }^{11}$ PAPSI 2003, h. 195.

${ }^{12}$ Farah Margaretha, teori dan aplikasi manajemen keuangan. Grasindo: Jakarta, 2004. h. 12 
bank selama periode tertentu yang dikelompokkan dalam aktivitas operasi, investasi, dan pendanaan selama satu periode tertentu. ${ }^{13}$

d. Laporan perubahan ekuitas adalah laporan yang menunjukkan perubahan ekuitas bank yang menggambarkan peningkatan atau penurunan aktiva bersih atau kekayaan selama periode pelaporan. ${ }^{14}$

e. Laporan perubahan dana investasi terikat (Mudharabah Muqayyadah) adalah laporan dari akad mudharabah dimana shahibul maal memberikan batasan kepada mudharib mengenai tempat, cara, dan objek investasi. Laporan perubahan dana investasi terikat memisahkan dana investasi terikat berdasarkan sumber dana dan memisahkan investasi berdasarkan jenisnya.

f. Pelaporan sumber dan penggunaan dana zakat, infaq, dan sadaqah merupakan laporan yang menunjukkan sumber dan penggunaan dana selama suatu jangka waktu tertentu, serta saldo ZIS pada tanggal tertentu. $^{15}$

g. Laporan sumber dan penggunaan dana qard merupakan laporan yang menunjukkan sumber dan penggunaan dana selama suatu jangka waktu tertentu, serta saldo qard pada tanggal tertentu. ${ }^{16}$

h. Catatan atas laporan keuangan merupakan bagian tak terpisahkan dari laporan keuangan. Catatan atas laporan keuangan memberikan penjelasan mengenai gambaran umum bank syariah, ikhtisar kebijakan akuntansi, penjelasan pos-pos laporan keuangan dan informasi penting lainnya. ${ }^{17}$

\section{Fungsi Laporan Keuangan}

Sebagai bahan informasi yang dapat digunakan oleh pihak-pihak yang membutuhkan, laporan keuangan setidaknya harus berfungsi sebagai berikut: ${ }^{18}$

\footnotetext{
${ }^{13}$ PAPSI 2003,h. 205.

${ }^{14}$ Ibid, h. 213

${ }^{15}$ Ibid, h. 224

${ }^{16}$ Ibid, h. 227

${ }^{17}$ Ibid, h. 231

${ }^{18}$ Ibid, h. 2
} 
a. Menyediakan informasi yang bermanfaat bagi pihak-pihak yang berkepentingan dalam pengambilan keputusan yang rasional. Pihakpihak yang berkepentingan antara lain:

1). Sahibul maal/pemilik dana

2). Kreditur

3). Pembayar zakat, infak, dan sadaqah

4). Pemegang saham

5). Otoritas pengawasan

6). Bank Indonesia

7). Pemerintah

8). Lembaga penjamin simpanan

9). Masyarakat

b. Informasi dalam menilai prospek arus kas, bertujuan untuk memberikan informasi yang dapat mendukung investor/pemilik dana, kreditur, dan pihak-pihak lain dalam memperkirakan jumlah, aset, dan ketidakpastian dalam penerimaan kas di masa depan atas deviden, bagi hasil, dan hasil dari penjualan, pelunasan (redemption), dan jatuh tempo dari surat berharga atau pinjaman.

c. Informasi atas sumber daya ekonomi, bertujuan memberikan informasi tentang sumber daya ekonomis bank (economic resources), kewajiban bank untuk mengalihkan sumber daya tersebut kepada entitas lain atau pemilik saham serta kemungkinan terjadinya transaksi, dan peristiwa yang dapat mempengaruhi perubahan sumber daya tersebut.

d. Informasi mengenai kepatuhan bank terhadap prinsip syariah serta informasi mengenai pendapatan dan pengeluaran yang tidak sesuai dengan prinsip syariah dan pegelolaan pendapatan dana bank tersebut.

e. Informasi untuk membantu pihak terkait di dalam menentukan zakat bank atau pihak lainnya.

f. Informasi untuk membantu mengevaluasi pemenuhan bank terhadap tanggung jawab amanah dalam mengamankan dana, menginvestasikannya pada tingkat keuntungan yang rasional.

g. Informasi mengenai pemenuhan fungsi sosial bank. 


\section{Acuan Penyusunan Laporan Keuangan}

Penyusunan laporan keuangan bank syariah didasarkan dari beberapa acuan yang relevan, adapun acuan tersebut adalah: ${ }^{19}$

a. Peraturan yang dikeluarkan oleh Bank Indonesia

b. Kerangka Dasar Penyusunan dan Penyajian Laporan Keuangan Umum, Kerangka Dasar Penyusunan dan Penyajian Laporan Keuangan Syariah, Pernyataan Standar Akuntansi Keuangan Umum, Pernyataan Standar Akuntansi Keuangan Syariah (PSAKS) dan Interprestasi Standar Akuntansi Keuangan (ISAK).

c. Accounting and Auditing Standard for Islamic Financial Institutions yang dikeluarkan oleh AAOIFI (Accounting and Auditing Organization of Islamic Financial Institutions).

d. International Accounting Standard (IAS), Statement of Financial Accounting Standard (SFAS), sepanjang tidak bertentangan dengan prinsip syariah.

e. Peraturan perundang-undangan yang relevan dengan laporan keuangan.

f. Praktik-praktik akuntansi yang berlaku umum, sepanjang tidak bertentangan dengan prinsip syariah.

\section{Keterbatasan Laporan Keuangan}

Pengambilan keputusan ekonomi tidak dapat semata-mata didasarkan atas informasi yang terdapat dalam laporan keuangan. Hal ini disebabkan laporan keuangan memiliki keterbatasan, antara lain: ${ }^{20}$

a. Bersifat historis yang menunjukkan transaksi dan peristiwa yang telah lampau.

b. Bersifat umum, baik dari sisi informasi maupun manfaat bagi pihak pengguna.

c. Bersifat lebih menekankan pada penyajian suatu peristiwa atau transaksi sesuai substansinya dan realitas ekonomi daripada bentuk

${ }^{19}$ Tim Penyusun Pedoman Akuntansi Perbankan Syariah Indonesia (IAI), Pedoman Akuntansi Perbankan Syariah Indonesia (Jakarta: Ikatan Akuntan Indonesia, 2003). h. 3

${ }^{20}$ Tim Penyusun Pedoman Akuntansi Perbankan Syariah Indonesia (IAI), Pedoman Akuntansi Perbankan Syariah Indonesia (Jakarta: Ikatan Akuntan Indonesia, 2003). h. 17 
hukumnya (formalitas).

d. Hanya melaporkan informasi yang material.

e. Informasi yang bersifat kualitatif dan fakta yang tidak dapat dikuantifikasikan umumnya diabaikan.

\section{Analisis Laporan Keuangan (Financial Statement Analysis)}

Analisis laporan keuangan (financial Statement analysis) adalah menghubungkan angka-angka yang terdapat dalam laporan keuangan dengan angka lain atau menjelaskan perubahan (trend)nya. Angka-angka dalam laporan keuangan akan menjadi sedikit artinya kalau dilihat secara sendirisendiri. Dengan analisis, pemakaian laporan keuangan lebih mudah menginterpretasikannya.

Interpretasi laporan keuangan (financial Statement Interpretation) menghubungkan angka-angka dalam laporan keuangan, termasuk hasil analisisnya, dengan keputusan usaha yang akan diambil. Analisis terhadap laporan keuangan suatu perusahaan pada dasarnya karena ingin mengetahui tingkat profitabilitas (keuntungan) dan tingkat risiko atau tingkat kesehatan suatu perusahaan. Analisis keuangan yang mencakup analisis rasio keuangan, analisis kelemahan dan kekuatan di bidang finansial akan sangat membantu dalam menilai prestasi manajemen masa lalu dan prospeknya di masa datang. Laporan keuangan yang disusun secara baik dan akurat dapat memberikan gambaran keadaan yang nyata mengenai hasil atau prestasi yang telah dicapai oleh suatu perusahaan selama kurun waktu tertentu, keadaan inilah yang digunakan untuk menilai kinerja keuangan.

\section{Tujuan analisis laporan keuangan bank}

Analisis laporan keuangan bank pada dasarnya untuk mengetahui masalah: ${ }^{21}$

a. Posisi keuangan suatu bank.

b. Besarnya hasil operasi bank.

c. Perubahan-perubahan yang terjadi dalam posisi keuangan bank.

${ }^{21}$ Malayu S. P. Hasibuan, Manajemen Perbankan: Dasar dan Kunci Kehidupan Perekonomian, cet 1, (CV: Haji Masagun: Jakarta), 1993. h 157. 
d. Laporan data-data di laporan rugi-laba bank.

e. Merumuskan indikator-indikator penunjang dan penghambat operasional bank dalam pencapaian tujuan untuk tools of management bank itu.

\section{Definisi Profitabilitas}

Rentabilitas atau Profitabilitas adalah alat ukur menganalisa atau mengukur tingkat efisiensi usaha dan profitabilitas yang dicapai oleh bank yang bersangkutan. ${ }^{22}$ Profitabilitas adalah ukuran spesifik dari performance sebuah bank, dimana ia merupakan tujuan dari manajemen perusahaan dengan memaksimalkan nilai dari para pemegang saham, optimalisasi dari berbagai tingkat return, dan minimalisasi resiko yang ada. Tujuan analisis profitabilitas sebuah bank adalah untuk mengukur tingkat efisiensi usaha dan profitabilitas yang dicapai oleh bank yang bersangkutan. ${ }^{23}$

$$
\mathrm{ROE}=\frac{\text { Net Income }}{\text { Total Equity }}
$$

Bagi para pemilik bank/pemegang saham bank yang bersangkutan maka rumus ini mempunyai arti yang sangat penting untuk mengukur kemampuan manajemen dalam mengelola capital yang tersedia untuk mendapatkan Net Income. Bagi manajemen bank yang mampu menaikkan Return On Equity biasanya ada petunjuk tentang kemampuan manajemen bank yang bersangkutan dalam menaikkan income-nya. Kenaikan Return On Equity biasanya juga diikuti kenaikan dari saham-saham bank yang bersangkutan di pasar. ${ }^{24}$ Semakin tinggi return semakin baik, berarti dividen yang dibagikan atau ditanamkan kembali sebagai retained earning juga semakin besar.

\section{Rasio Kesehatan Bank}

\section{CAR (Capital Adequacy Ratio)}

Modal merupakan salah satu faktor penting dalam rangka pengembangan

${ }^{22}$ Lukman Dendawijaya, Manajemen Perbankan Ed. 2, (Galia Indonesia: Bogor), 2005. h. 118

${ }^{23}$ Teguh Pudja Muljono, Analisa laporan keuangan untuk perbankan, (Djambatan: Jakarta), 1990.h. 73

${ }^{24}$ Teguh pudja muljono, Analisa laporan keuangan untuk perbankan, 1990.h. 74 
usaha bisnis dan menampung resiko kerugian, semakin tinggi CAR maka semakin kuat kemampuan bank tersebut untuk menanggung resiko dari setiap kredit/aktiva produktif yang berisiko. Jika nilai CAR tinggi (sesuai ketentuan BI 8\%) berarti bank tersebut mampu membiayai operasi bank, keadaan yang menguntungkan bank tersebut akan memberikan kontribusi yang cukup besar bagi profitabilitas. ${ }^{25}$ Dalam menelaah CAR bank syariah, terlebih dahulu harus dipertimbangkan, bahwa aktiva bank syariah dapat dibagi atas: ${ }^{26}$

a. Aktiva yang didanai oleh modal sendiri dan/kewajiban atau hutang (wadiah atau qard dan sejenisnya).

b. Aktiva yang didanai oleh rekening bagi hasil (Profit and loss Sharing Investment Account)yaitu mudharabah (General Investment Account/ mudharabah mutlaqah, Restricted Investment Account/mudharabah muqayyadah)

CAR diukur dengan membagi modal dengan aktiva tertimbang menurut resiko (ATMR).

\section{$\mathrm{CAR}=\frac{\text { Modal Bank }}{\text { Total ATMR }}$}

Hasil perhitungan rasio diatas kemudian dibandingkan dengan kewajiban penyediaan modal minimum (yakni senesar 8\%). Berdasarkan hasil perbandingan tersebut, dapatlah diketahui apakah bank yang bersangkutan telah memenuhi ketentuan CAR atau tidak. Jika hasil perbandingan antara rasio perhitungan rasio modal dan kewajiban penyediaan modal minimum sama dengan $100 \%$ atau lebih, modal bank yang bersangkutan telah memenuhi ketentuan CAR. Sebaliknya, bila hasilnya kurang dari 100\%, modal bank tersebut tidak memenuhi ketentuan CAR. ${ }^{27}$

\section{FDR (Financing Deposit to Ratio)}

FDR (Financing Deposit to Ratio) adalah rasio antara seluruh jumlah kredit

${ }^{25}$ Mudrajad Kuncoro dan Suhardjono, Manajemen Perbankan: Teori dan Aplikasi, (Penerbit BPFE Yogyakarta: Yogyakarta), 2002. h. 573

${ }^{26}$ Zainul Arifin, Dasar-Dasar Manajemen Bank Syariah.. h.138.

${ }^{27}$ Lukman Dendawijaya, Manajemen Perbankan Ed. 2, 2005. h. 41 
yang diberikan dengan dana yang diterima bank. ${ }^{28}$ Kebutuhan likuiditas setiap bank berbeda-beda tergantung antara lain pada kekhususan usaha bank, besarnya bank dan sebagainya.

Rasio ini menunjukkan salah satu penilaian likuiditas bank dan dapat dirumuskan sebagai berikut:

\section{$\mathrm{FDR}=\frac{\text { Pembiayaan yang diberikan }}{\text { Dana Masyarakat }}$}

FDR tersebut menyatakan seberapa jauh kemampuan bank dalam membayar kembali penarikan dana yang dilakukan deposan dengan mengandalkan kredit yang diberikan sebagai sumber likuiditasnya. Dengan kata lain, seberapa jauh pemberian kredit kepada nasabah kredt dapat mengimbangi kewajiban bank untuk segera memenuhi permintaan deposan yang ingin menarik kembali uangnya yang telah digunakan oleh bank untuk memberikan kredit.

Semakin tinggi rasio tersebut memberikan indikasi semakin rendahnya kemampuan likuiditas bank yang bersangkutan. Hal ini disebabkan karena jumlah dana yang diperlukan untuk membiayai kredit menjadi semakin besar. ${ }^{29}$

Rasio ini juga merupakan indikator kerawanan dan kemampuan dari suatu bank. Sebagian praktisi perbankan menyepakati bahwa batas aman dari Financing Deposit to Ratio suatu bank adalah sekitar 80\%. Namun, batas toleransi antara $85 \%$ dan $100 \% .^{30}$

\section{BOPO (Biaya Operasional terhadap Pendapatan Operasional)}

BOPO menurut kamus keuangan adalah kelompok rasio yang mengukur efisiensi dan efektivitas operasional suatu perusahaan dengan jalur membandingkan satu terhadap lainnya. Berbagai angka pendapatan dan pengeluaran dari laporan rugi laba dan terhadap angka-angka dalam neraca. Rasio biaya operasional adalah perbandingan antara

\footnotetext{
${ }^{28}$ Ibid. h. 116

${ }^{29}$ Ibid h. 116

${ }^{30}$ Ibid h. 117
} 
biaya operasional dan pendapatan operasional. Rasio biaya operasional digunakan untuk mengukur tingkat efisiensi dan kemampuan bank dalam melakukan kegiatan operasi. ${ }^{31}$

Semakin rendah BOPO berarti semakin efisien bank tersebut dalam mengendalikan biaya operasionalnya, dengan adanya efisiensi biaya maka keuntungan yang diperoleh bank akan semakin besar.

\section{BOPO $=\frac{\text { Biaya Operasional }}{\text { Pendapatan Operasional }}$}

BOPO merupakan upaya bank untuk meminimalkan resiko operasional, yang merupakan ketidakpastian mengenai kegiatan usaha bank. Resiko operasional berasal dari kerugian operasional bila terjadi penurunan keuntungan yang dipengaruhi oleh struktur biaya operasional bank, dan kemungkinan terjadinya kegagalan atas jasa-jasa dan produkproduk yang ditawarkan.

\section{NPF (Non-Performing Financing)}

Perkembangan pemberian pembiayaan yang paling tidak mengembirakan bagi pihak bank adalah apabila pembiayaan yang diberikannya ternyata menjadi bermasalah. Hal ini terutama disebabkan oleh kegagalan pihak debitur memenuhi kewajibannya untuk membayar angsuran (cicilan) pokok pembiayaan beserta bagi hasil yang telah disepakati kedua belah pihak dalam perjanjian pembiayaan. ${ }^{32}$

NPF (Non-Performing Financing) adalah tingkat pengembalian pembiayaan yang diberikan deposan kepada bank dengan kata lain NPF merupakan tingkat pembiayaan macet pada bank tersebut. NPF diketahui dengan cara menghitung Pembiayaan Non Lancar Terhadap Total Pembiayaan. Apabila semakin rendah NPF maka bank tersebut akan semakin mengalami keuntungan, sebaliknya bila tingkat NPF tinggi bank tersebut akan mengalami kerugian yang diakibatkan tingkat pengembalian kredit macet.

\footnotetext{
${ }^{31}$ Ibid h. 120

${ }^{32}$ Ibid, h. 81
} 


\section{NPF $=\frac{\text { Pembiyaan non Lancar }}{\text { Total Pembiayaan }}$}

Implikasi bagi pihak bank sebagai akibat dari timbulnya pembiayaan bermasalah tersebut dapat berupa berikut ini: ${ }^{33}$

a. Hilangnya kesempatan untuk memperoleh income (pendapata) dari kredit yang diberikannya, sehingga mengurangi perolehan laba dan berpengaruh buruk bagi profitabilitas bank,

b. Rasio kualitas aktiva produktif atau yang lebih dikenal dengan BDR (bad debt ratio) menjadi semakin besar yang menggambarkan terjadinya situasi yang memburuk.

c. Bank harus memperbesar penyisihan untuk cadangan aktiva produktif yang diklasifikasikan berdasarkan ketentuan yang ada. Hal ini pada akhirnya akan mengurangi besarnya modal bank dan akan sangat berpengaruh terhadap CAR (Capital Adequacy Ratio).

d. Return on assets (ROA) mengalami penurunan.

e. Sebagai akibat dari komplikasi butir 2, 3, dan 4 tersebut di atas adalah menurunnya nilai tingkat kesehatan bank berdasarkan perhitungan menurut metode CAMEL.

\section{Strategi Bank Muamalat Indonesia}

Dalam menerapkan konsep-konsep syari'ah yang Islami dan meningkatkan fee based income, untuk mencapai tujuannya, Bank Muamalat Indonesia mendasarkan usahanya dengan kegiatan sebagai berikut:

a. Sasaran pembinaan, yaitu membina dan mempercepat perkembangan mayarakat ekonomi menengah ke bawah bangsa Indonesia untuk menjembatani kesenjangan sosial ekonomi yang terjadi karena dampak pembangunan, sehingga terbentuk dasar yang kokoh bagi pengembangan manusia Indonesia seutuhnya dalam pembangunan nasional jangka panjang 25 tahun ke-dua.

b. Strategi pengembangan yaitu:

1. Bekerjasama dengan baik dengan bank-bank perkreditan rakyat

${ }^{33}$ Ibid h. $82-83$ 
(BPR) yang telah ada. Mendorong pengembangan BPR baru di daerah-daerah potensial.

2. Bekerjasama dengan Badan Amil Zakat, Infaq dan Sedekah (BAZIS) untuk menginsentifkan pengelolaan dana ZIS.

3. Merangsang lembaga penyedia bantuan teknik menajemen pengusaha kecil dan menengah untuk tumbuh dan berkembang lebih baik.

4. Merangsang lembaga penyedia bantuan pembinaan keterampilan akuntansi untuk tumbuh dan berkembang lebih baik.

5. Mengembangkan peranan kelembagaan penyediaan teknologi paska panen.

6. Mengembangkan peranan kelembagaan pemasaran hasil produksi. ${ }^{34}$

\section{Produk Bank PT Bank Muamalat Indonesia}

\section{Produk Penghimpunan Dana}
a. Tabungan Ummat
b. Tabungan Arafah
c. Deposito Mudharabah
d. Deposito Fulinves
e. Giro Wadiah

2. Produk Penanaman Dana
a. Murabahah
b. Salam
c. Istishna'

3. Jasa Layanan

a. Pembayaran Zakat, Infak, Sedekah (ZIS)

b. Jasa-jasa lainnya

4. Sistem Bagi Hasil pada Bank Muamalat Indonesia

Penetapan bagi hasil di Bank Muamalat dilakukan dengan terlebih dahulu mengitung HI-1000 (baca: Ha-i-seribu), yakni angka yang me- 
nunjukkan hasil investasi yang diperoleh dari penyaluran setiap seribu rupiah dana nasabah. Sebagai contoh: HI-1000 Rupiah bulan Juni 2005 adalah 11,57. Hal tersebut berarti bahwa dari setiap Rp. 1.000,- dana nasabah yang dikelola Bank Muamalat akan menghasilkan Rp. 11,57 (HI1000 sebelum bagi hasil). Apabila nisbah bagi hasil antara nasabah dan bank untuk deposito 1 bulan adalah 52:48, maka dari Rp. 11,57 tersebut, untuk porsi nasabah dikalikan dahulu dengan $52 \%$ sehingga untuk setiap Rp. 1.000,- dana yang dimiliki, nasabah akan memperoleh bagi hasil sebesar Rp. 6,01 (berarti HI-1000 nasabah = 6,01 rupiah). Secara umum hal tersebut dirumuskan sebagai berikut: ${ }^{35}$

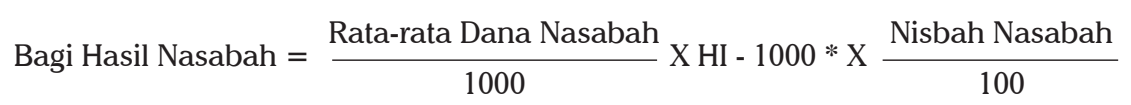

*) HI-1000 Sebelum Bagi Hasil

\section{Deskripsi Data}

Data-data yang diperlukan dalam analisis ini didapat dari laporan keuangan bulanan PT Bank Muamalat Indonesia Tbk, yang dimulai dari Januari: 2005-April: 2008. dengan demikian diharapkan dapat diketahui perkembangan laporan keuangan tiap bulannya. Dari hasil olah data yang dilakukan dengan menggunakan SPSS for windows versi 11.0. dapat dijelaskan mengenai variabel-variabel yang terdapat pada model regresi berganda dapat dilihat pada table-tabel dibawah ini:

\section{Data ROE (Return on Equity)}

Model Awal Regresi

Pengujian asumsi klasik meliputi pengujian Multikolinieritas, Heterokedasitas, Autokorelasi.

a. Uji Multikolinieritas

Uji ini bertujuan bertujuan untuk menguji apakah pada model regresi ditemukan adanya korelasi antara variabel independent. Jika terjadi korelasi, maka terdapat multikolinieritas (multikol). Dimana model

${ }^{35}$ Diakses tanggal 3-11-2008 dari http:// www.muamalat-institut.com 
regresi yang baik seharusnya tidak terjadi korelasi diantara variabel independent.

b. Uji Heterokedasitas

Uji ini untuk menguji apakah dalam sebuah model regresi terjadi ketidaksamaan varians dari residual dari satu pengamatan ke pengamatan yang lain tetap, maka hal tersebut disebut Homoskedasitas. Dan jika varians berbeda disebut sebagai heterokedasitas. Model regresi yang baik adalah tidak terjadi heterokedasitas. ${ }^{36}$

Dari hasil grafik Heterokedasitas, terlihat titik-titik yang menyebar secara acak, dan tidak membentuk suatu pola tertentu yang jelas. Titik-titik tersebut menyebar baik diatas namun dibawah angka 0 pada sumbu Y. Hal ini berarti tidak terjadi heterokedasitas pada model regresi berganda ini , sehingga model regresi berganda layak dipakai untuk memprediksi ROE terhadap variabel independen lainnya, hal ini terlihat jelas pada gambar dibawah ini:

Gambar 4.2

Hasil Uji Heterokedasitas

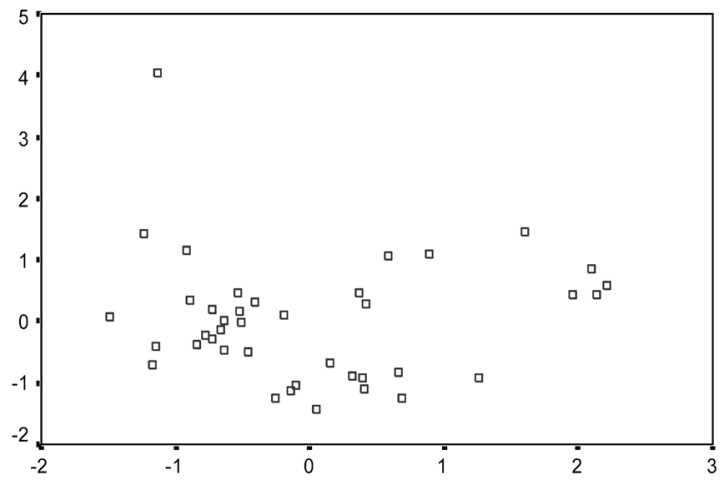

Sumber: data olahan SPSS 11.0

c. Uji Normalitas

Uji ini untuk menguji apakah dalam sebuah model regresi, variabel

${ }^{36}$ Singgih santoso, modul menggunakan SPSS untuk Statistik Parametrik. (Jakarta: PT. Elex Media Komputindo) 2005. h. 137 
dependen, variabel independen atau keduanya mempunyai distribusi normal ataukah tidak. Model regresi yang baik adalah distribusi data normal atau mendekati normal. Dari hasil pengujian Normalitas diperoleh suatu grafik, dimana pada grafik hasil uji normalitas terlihat bahwa titik-titik menyebar disekitar garis diagonal, serta penyebarannya mengikuti arah garis diagonal. Hasil tersebut dapat terlihat pada grafik hasil pengolahan SPSS 11.0 dibawah ini:

Gambar 4.3

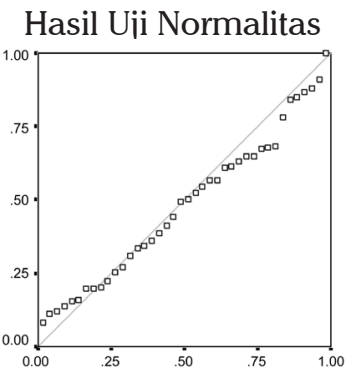

Sumber: data olahan SPSS 11.0

\section{Hasil Model Awal Regresi}

Dari hasil uji MWD maka dapat dilihat model linier adalah baik, karena nilai Durbin-Watson yang diperoleh dari hasil analisis regresi sebesar 1.510. Hal ini menunjukkan bahwa angka DW diantara $-2<$ DW $<+2$ maka Ho diterima yaitu model regresi tidak terdapat masalah dan model ini layak untuk digunakan.

$\mathrm{Y}=185,347-1,134 \mathrm{CAR}-7.612 \mathrm{FDR}-1,753 \mathrm{BOPO}+0,769 \mathrm{NPF}$ dapat diartikan bahwa:

1. Nilai elastisitas konstanta sebesar 185,347 menunjukkan bahwa apabila nilai CAR, FDR, BOPO dan NPF adalah 0 (nol) maka nilai Y adalah 185,347.

2. $\mathrm{CAR}=-1,134$

Nilai elastisitas CAR sebesar -1,134 menunjukkan bahwa CAR naik sebesar 1\% maka profitabilitas akan mengalami penurunan sebesar $1,134 \%$ dengan asumsi variabel lain dianggap tetap.

3. $\quad$ FDR $=-7.612$

Nilai elastisitas FDR sebesar -7.612 menunjukkan bahwa FDR naik sebesar 1\% maka profitabilitas akan mengalami penurunan sebesar $-7.612 \%$ dengan asumsi variabel lain dianggap tetap. 
4. $\mathrm{BOPO}=-1,753$

Nilai elastisitas BOPO sebesar -1,753 menunjukkan bahwa BOPO sebesar 1\% maka profitabilitas akan mengalami penurunan sebesar sebesar $-1,753 \%$ dengan asumsi variabel lain dianggap tetap.

5. $\quad \mathrm{NPF}=0,769$

Nilai elastisitas NPF sebesar 0,769 menunjukkan bahwa peningkatan NPF sebesar 1\% akan meningkatkan profitabilitas bank sebesar $0,769 \%$ dengan asumsi variabel lain dianggap tetap.

\section{Pengujian Hipotesis}

Setelah pengujian persyaratan analisis dan asumsi dasar regresi, langkah selanjutnya melakukan pengujian signifikan model dan interpretasi model regresi, untuk melihat pengaruh variabel independen terhadap variabel dependen secara individual. Secara statistik dapat diukur dari nilai statistik Uji t dan Uji F (ANOVA).

Hasil Uji F

Tabel 4.14

Hasil Uji FANOVA

\begin{tabular}{|c|c|c|c|c|c|c|}
\hline Model & & Sum of Squares & df & Mean Square & F & Sig. \\
\hline 1 & Regression & 1076.093 & 4 & 269.023 & 34.720 & .000 \\
\hline & Residual & 271.195 & 35 & 7.748 & & \\
\hline & Total & 1347.288 & 39 & & & \\
\hline
\end{tabular}

a Predictors: (Constant), NPF, BOPO, CAR, FDR

b Dependent Variabel: ROE

Sumber: data olahan SPSS 11.0

Uji F digunakan untuk mengetahui hubungan variabel independen secara simultan (bersama-sama) terhadap variabel dependen. Hasil dari uji pada tabel diatas menunjukkan semua angka signifikan, karena tingkat probabilitas sig 0,000 . Nilai probabilitas $(0,000)$ lebih kecil dari 0,05 . F hitung sebesar 34,720 dan F tabel sebesar 2,64. Maka dapat disimpulkan bahwa terdapat pengaruh yang signifikan antara CAR, FDR, BOPO, dan NPF 
terhadap ROE, maka Ho ditolak dan Ha diterima karena F hitung $(34,720)$ $>$ F tabel $(2,64)$.

Uji F dapat digambarkan sebagai berikut:

F hitung $>$ F tabel, maka tolak Ho

$34,720>2,64$

Gambar 4.4

Daerah penerimaan Ho dan Penolakan Ho

Uji Dua Pihak

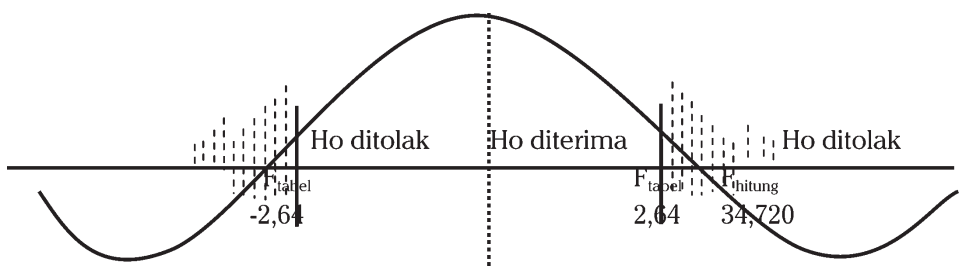

Hasil Uji $t$

Tabel 4.15

Hasil Uji t

Coefficients

\begin{tabular}{|c|c|c|c|c|c|c|}
\hline \multicolumn{2}{|c|}{} & $\begin{array}{c}\text { Unstandardized } \\
\text { Coefficients }\end{array}$ & & $\begin{array}{c}\text { Standardized } \\
\text { Coefficients }\end{array}$ & $\mathrm{t}$ & Sig. \\
\cline { 2 - 7 } Model & B & Std. Error & Beta & & \\
\hline 1 & (Constant) & 185.347 & 15.788 & & 11.740 & .000 \\
\hline & CAR & -1.134 & .212 & -.472 & -5.353 & .000 \\
\hline & FDR & $-7.612 \mathrm{E}-02$ & .087 & -.079 & -.874 & .388 \\
\hline & BOPO & -1.753 & .182 & -.771 & -9.647 & .000 \\
\hline & NPF & .769 & .465 & .160 & 1.654 & .107 \\
\hline
\end{tabular}

a Dependent Variabel: ROE

Sumber: data olahan SPSS 11.0

Uji t digunakan untuk mengetahui hubungan masing-masing variabel independen secara individual terhadap variabel dependen. Berdasarkan 
pengujian pada tabel diatas dapat disimpulkan sebagai berikut:

a. Pengaruh variabel CAR terhadap profitabilitas Bank Muamalat signifikan dimana nilai t hitung $(-5,353)<\mathrm{t}$ tabel $(-1,97)$ dan signifikansi sebesar $0,000<\alpha=5 \%(0,05)$, sehingga Ho ditolak dan Ha diterima. Maka dapat dirumuskan bahwa variabel CAR berpengaruh secara parsial terhadap variabel ROE periode Januari 2005-April 2008, yang memiliki hubungan negatif yang signifikan, artinya semakin besar nilai CAR maka semakin kecil tingkat profitabilitas bank yang dihasilkan oleh bank.

b. Pengaruh variabel FDR terhadap profitabilitas Bank Muamalat tidak signifikan dimana nilai $\mathrm{t}$ hitung $(-0,874)>\mathrm{t}$ tabel $(-1,97)$ dan signifikansi sebesar $0,388>a=5 \%(0,05)$, sehingga Ho diterima dan Ha ditolak. Maka dapat dirumuskan bahwa variabel FDR tidak berpengaruh secara parsial terhadap variabel ROE periode Januari 2005- April 2008.

Gambar 4.6

Daerah penerimaan Ho dan Penolakan Ho

Uji Dua Pihak

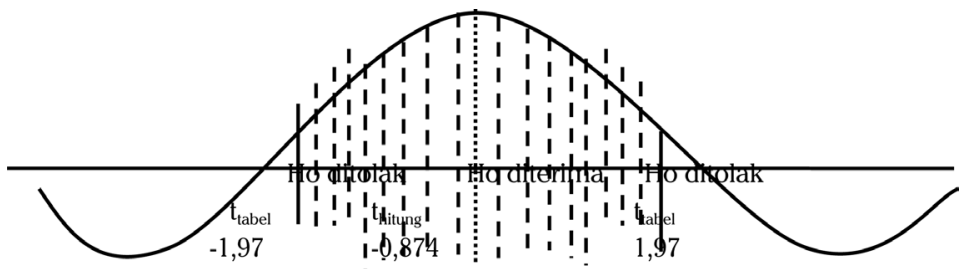

c. Pengaruh variabel BOPO terhadap profitabilitas Bank Muamalat signifikan dimana nilai $\mathrm{t}$ hitung $(-9,647)<\mathrm{t}$ tabel $(-1,97)$ dan signifikansi sebesar $0,000<\alpha=5 \%(0,05)$, sehingga Ho ditolak dan Ha diterima. Maka dapat dirumuskan bahwa variabel BOPO berpengaruh secara parsial terhadap variabel ROE periode Januari 2005- April 2008, yang memiliki hubungan negatif yang signifikan, artinya semakin besar nilai BOPO maka semakin kecil tingkat profitabilitas bank yang dihasilkan oleh bank. 
Gambar 4.7

Daerah penerimaan Ho dan Penolakan Ho

Uji Dua Pihak

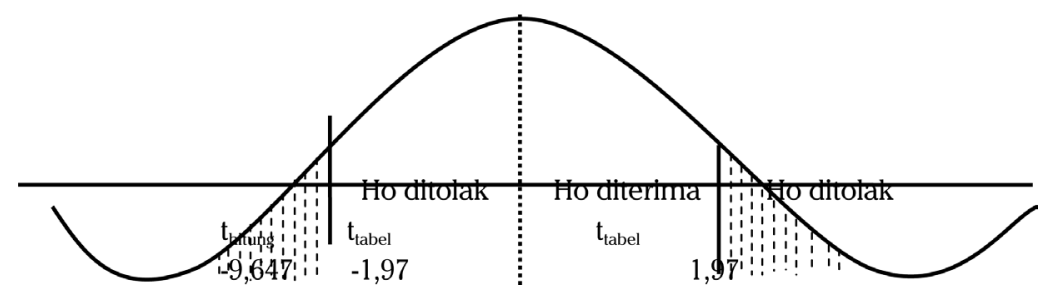

d. Pengaruh variabel NPF terhadap profitabilitas Bank Muamalat tidak signifikan dimana nilai $\mathrm{t}$ hitung $(1,654)>\mathrm{t}$ tabel $(-1,97)$ dan signifikansi sebesar $0,107>\alpha=5 \%(0,05)$, sehingga Ho diterima dan Ha ditolak. Maka dapat dirumuskan bahwa variabel NPF tidak berpengaruh secara parsial terhadap variabel ROE periode Januari 2005- April 2008.

Gambar 4.8

Daerah penerimaan Ho dan Penolakan Ho

Uji Dua Pihak

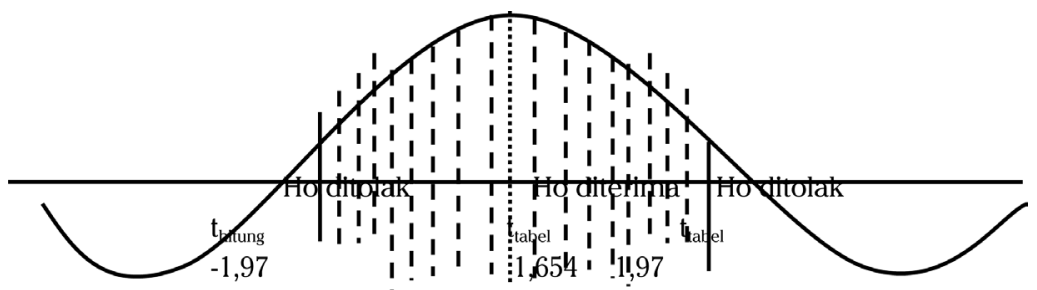

\section{Hasil SPSS Korelasi Product Moment}

Tabel 4.16

Uji korelasi CAR, FDR, BOPO, NPF dan ROE

Sumber: data olahan SPSS 11.0

Dari analisis korelasi pada tabel 4.14 diatas terlihat bahwa korelasi antara CAR dengan ROE sebesar -0,484. Hal ini menunjukkan hubungan kedua variabel tersebut adalah kuat dan berlawanan arah (memiliki 
hubungan negatif). Korelasi kedua variabel tersebut signifikan karena angka signifikansi sebesar $0,002<0,05$.

Sedangkan korelasi antara BOPO dengan ROE sebesar -0,721. Hal ini menunjukkan hubungan kedua variabel tersebut adalah kuat dan berlawanan arah (memiliki hubungan negatif). Korelasi kedua variabel tersebut signifikan karena angka signifikansi sebesar 0,000 $<0,05$.

Korelasi antara FDR dengan ROE sebesar 0,050. Hal ini menunjukkan hubungan kedua variabel tersebut adalah lemah dan searah (memiliki hubungan positif). Semakin besar nilai FDR maka semakin besar ROE yang didapat oleh Bank Muamalat. Korelasi kedua variabel tersebut tidak signifikan karena angka signifikansi sebesar 0,761 > 0,05.

Dan korelasi antara NPF dengan ROE sebesar 0,115. Hal ini menunjukkan hubungan kedua variabel tersebut adalah lemah dan searah (memiliki hubungan positif). Semakin besar nilai NPF maka semakin besar mempengaruhi ROE yang didapat oleh Bank Muamalat. Korelasi kedua variabel tersebut tidak signifikan karena angka signifikansi sebesar 0,478 $>0,05$.

\section{Interprestasi Koefisien Variabel Independen}

Berdasarkan Uji t, dapat diketahui bahwa secara parsial terdapat pengaruh yang signifikan variabel CAR dan BOPO terhadap profitabilitas Bank Muamalat.sedangkan variabel FDR dan NPF secara parsial tidak mempunyai pengaruh yang signifikan terhadap profitabilitas bank Muamalat.

\section{Uji Regresi Stepwise}

Uji regresi stepwise dilakukan untuk menghilangkan variabel independent yang tidak signifikan mempengaruhi variabel dependen. Setelah dilakukan uji regresi stepwise, berdasarkan tabel Tabel 4.17 dibawah ini, terjadi perubahan persamaan regresi, yaitu menjadi:

persamaan $\mathrm{Y}=77,335-1,233 \mathrm{CAR}-1,685 \mathrm{BOPO}$

Tabel 4.17

Sumber: data olahan SPSS 11.0

Hasil Uji Koefisien Determinasi (R Square)

Tabel 4.18 diatas juga menunjukkan koefisien determinasi (R 
Square) adalah sebesar 0.783 atau 78,3\% yang berarti bahwa 78,3\% tingkat profitabilitas Bank Muamalat dapat dijelaskan oleh CAR dan BOPO, selebihnya dijelaskan oleh faktor lain seperti return bagi hasil, NPM (net profit margin) dan tidak termasuk dalam analisis ini. Hal tersebut juga menunjukkan kemampuan variabel-variabel independen dalam menjelaskan variabel dependen mempunyai korelasi cukup kuat.

Hasil Uji F Regresi Stepwise

Tabel 4.18

Hasil Uji F

ANOVA(c)

\begin{tabular}{|c|c|c|c|c|c|c|}
\hline \multirow{2}{*}{ Model } & & $\begin{array}{c}\text { Sum of } \\
\text { Squares }\end{array}$ & Df & $\begin{array}{c}\text { Mean } \\
\text { Square }\end{array}$ & F & Sig. \\
\hline \multirow{2}{*}{1} & Regression & 699.865 & 1 & 699.865 & 41.078 & $.000(\mathrm{a})$ \\
\cline { 2 - 7 } & Residual & 647.423 & 38 & 17.037 & & \\
\cline { 2 - 7 } & Total & 1347.288 & 39 & & & \\
\hline \multirow{2}{*}{2} & Regression & 1054.303 & 2 & 527.151 & 66.572 & $.000(\mathrm{~b})$ \\
\cline { 2 - 7 } & Residual & 292.986 & 37 & 7.919 & & \\
\cline { 2 - 7 } & & 1347.288 & 39 & & & \\
\hline
\end{tabular}

a Predictors: (Constant), bopo

b Predictors: (Constant), bopo, car

c Dependent Variable: roe

Sumber: data olahan SPSS 11.0

Uji F digunakan untuk mengetahui hubungan variabel independen secara simultan (bersama-sama) terhadap variabel dependen. Hasil dari uji pada tabel diatas menunjukkan semua angka signifikan, karena tingkat probabilitas sig 0,000 . Nilai probabilitas $(0,000)$ lebih kecil dari 0,05 . F hitung sebesar 66.572 dan $\mathrm{F}$ tabel sebesar 2,64. Maka dapat disimpulkan bahwa terdapat pengaruh yang signifikan antara CAR dan BOPO terhadap ROE, maka Ho ditolak dan Ha diterima karena F hitung (66.572) > F tabel $(2,64)$. 
Uji F dapat digambarkan sebagai berikut:

F hitung $>$ F tabel, maka tolak Ho

$66.572>2,64$

\section{Hasil Uji t Regresi Stepwise}

Uji $\mathrm{t}$ digunakan untuk mengetahui hubungan masing-masing variabel independen secara individual terhadap variabel dependen. Berdasarkan pengujian pada tabel diatas dapat disimpulkan sebagai berikut:

Pengaruh variabel CAR terhadap profitabilitas Bank Muamalat signifikan dimana nilai thitung $(-6.690)<\mathrm{t}$ tabel $(-1,97)$ dan signifikansi sebesar $0,000<\alpha=5 \%(0,05)$, sehingga Ho ditolak dan Ha diterima. Maka dapat dirumuskan bahwa variabel CAR berpengaruh secara parsial terhadap variabel ROE periode Januari 2005-April 2008, yang memiliki hubungan negatif yang signifikan, artinya semakin besar nilai CAR maka semakin kecil tingkat profitabilitas bank yang dihasilkan oleh bank.

Gambar 4.10

Daerah penerimaan Ho dan Penolakan Ho

Uji Dua Pihak

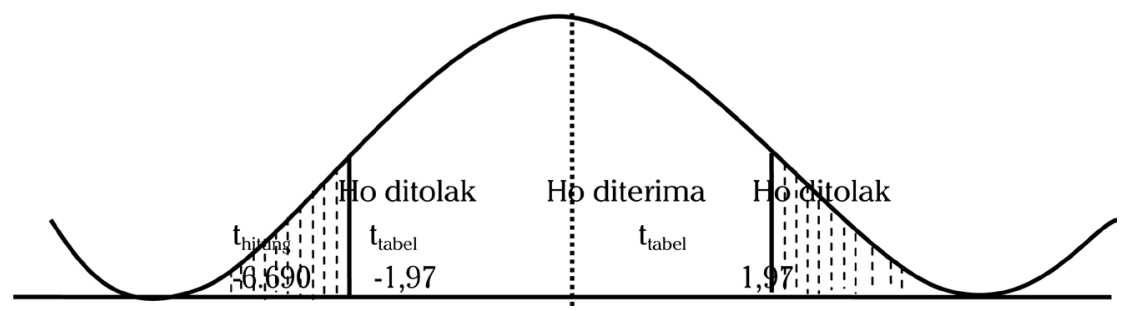

\section{Penutup}

Berdasarkan hasil analisis penelitian mengenai analisis tingkat profitabilitas pada Bank Muamalat, yang dianalisis dengan dua kali analisis yaitu analisis regresi ganda dan analisis regresi stepwise maka dapat disimpulkan sebagai berikut:

Dengan analisis regresi ganda: Dilihat dari R-squared sebesar 0,799 yang berarti bahwa 79,9\% profitabilitas mampu dijelaskan oleh variabel independen yang digunakan dalam model (CAR, FDR, BOPO, NPL) dan 
sisanya sebesar 20,1\% dijelaskan oleh variabel lain diluar model yang digunakan. Dari pengujian F statistik dengan menggunakan $\mathrm{a}=5 \%$ diperoleh F-tabel sebesar 2,64 sementara diperoleh F-statistik sebesar 34,72 yang berarti F-statistik > F-tabel, maka dapat disimpulkan bahwa semua variabel independen secara bersama-sama (simultan) mempengaruhi variabel dependen. Berdasarkan Uji t, dapat diketahui bahwa secara parsial terdapat pengaruh yang signifikan variabel CAR dan BOPO terhadap profitabilitas Bank Muamalat.sedangkan variabel FDR dan NPF secara parsial tidak mempunyai pengaruh yang signifikan terhadap profitabilitas bank Muamalat.

\section{Pustaka Acuan}

Al-Quran Al-karim dan Al-Hadis

Antonio. Syafi'i, bank dari teori ke praktik, Jakarta: Gema Insani, 2006

Arifin, Zainul., Dasar-Dasar Manajemen Bank Syariah. Jakarta: Pustaka alvabet. 2005

Dendawijaya, Lukman. Manajemen Perbankan Ed. 2, (Galia Indonesia: Bogor), 2005.

Firdaus, Rachmat dan maya ariyanti., Manajemen Perkreditan Bank Umum, Bandung, Alfabeta:2004

Harahap, Sofyan syafri., Analisis Kritis Atas Laporan Keuangan. Jakarta: PT RajaGrafindo Persada. 2002

Hasan, M. Iqbal., Pokok-Pokok Materi Statistic 2 (Statistic Infrensif), Jakarta, Bumi Aksara, 2003

http://www.muamalatbank.com

Kuncoro, Mudrajad dan Suhardjono, Manajemen Perbankan: Teori dan Aplikasi, (Penerbit BPFE Yogyakarta: Yogyakarta), 2002.

Mauludi, Ali., Statistika I Penelitian Ekonomi Islam dan Sosial, Ciputat, PT Prima Herza Lestari, 2006

Media Indonesia 11 Juli 2006 PPN bebani bank Syariah Muhammad, Manajemen Pembiayaan Bank Syariah. Yogyakarta, UPP AMP 
YPKN, 2005

Muljono, Teguh pudja., Analisa laporan keuangan untuk perbankan,

(Djambatan:Jakarta)1990.

Rivai, Veithzal., Credit Management Handbook: Teori, Konsep, Prosedur Dan Aplikasi Panduan Praktis Mahasiswa, Bankir Dan Nasabah, Jakarta, PT Raja Grafindo Persada, 2006

Santoso, Singgih., Latihan SPSS Statistik Parametrik, Jakarta, PT Elex Media Komputindo, 2000

Setia Atmaja, Lukas, Manajemen Keuangan edisi revisi. PT. ANDI, Yogyakarta. 2002.

Sinungan, Muchdarsyah., Manajemen Dana Bank. Bumi aksara, Jakarta: 2000

Siswanto, Sutojo., Strategi Manajemen Kredit Bank Umum, Jakarta, Damar Mulia Pustaka

Subiyanto, Ibnu ., Metodologi Penelitian. Manajemen dan Akuntansi, Ed.3, UKP UPP AMP YKPN, Yogyakarta: 2000

Sujoko, Efferin., dkk, Metode Penelitian Untuk Akuntansi, Suatu Pendekatan Praktis, Jawa Timur, Bayu Media Publishing 2004

Surat Edaran Bank Indonesia Nomor 3/30/DPNP tanggal 14 Desember 2001 Syafri Harahap, Sofyan. Analisis Kritis Atas Laporan Keuangan (Jakarta: PT RajaGrafindo Persada, 2002).

Surat Edaran Bank Indonesia Nomor 3/30/DPNP tanggal 14 Desember 2001

Tim Penyusun Pedoman Akuntansi Perbankan Syariah Indonesia (IAI), Pedoman Akuntansi Perbankan Syariah Indonesia (Jakarta: Ikatan Akuntan Indonesia, 2003).

Malayu S. P. Hasibuan, Manajemen Perbankan: Dasar dan Kunci Kehidupan Perekonomian, cet 1, (CV: Haji Masagun: Jakarta), 1993.

Pudja Muljono, Teguh. Analisa laporan keuangan untuk perbankan, (Djambatan: Jakarta), 1990. 